\title{
I. I. Овчиннікова
}

\section{ЛЕКСИКО-СЕМАНТИЧНА ГРУПА ДІССЛІВ ІНТЕЛЕКТУАЛЬНОЇ ДІЇ В УКРАЇНСЬКІЙ ЛІТЕРАТУРНІЙ МОВІ}

Овчиннікова I. I. Лексико-семантична група дієслів інтелектуальної дії в українській літературній мові.

Статтю присвячено дослідженню групи дієслівної лексики української літературної мови, що позначають інтелектуальні дії свідомого суб' єкта; аналізу семантичної категорії 'потенційна спостережуваність', регулярне вираження якої властиве українським дієсловам дії.

Ключові слова: дієслово, інтелектуальна дія, сема, категорія, спостережуваність, експлікація.

Овчинникова И. И. Лексико-семантическая группа глаголов интеллектуального действия в украинском литературном языке.

Статья посвящена исследованию группы глагольной лексики украинского литературного языка, которая обозначает интеллектуальное действие сознательного субъекта; анализу семантической категории 'потенциальная наблюдаемость', регулярное выражение которой присуще украинским глаголам действия.

Ключевые слова: глагол, интеллектуальное действие, сема, категория, наблюдаемость, експликация.

Ovchynnikova I. I. Lexical-semantic group of verbs predictive validity in Ukrainian literary language.

The article is devoted to the research of verbal lexis of Ukrainian language, where the definite sema 'observation' is not actualized, the analyze of semantic category 'potential observation', which the regular expression is characteristic of the action verbs.

Key words: verb, action, sema, category, observation, explication.

Дієслова зі значенням дії складають найбільший і найпродуктивніший шар лексики української мови, онтологічною сутністю якого є уявлення мовців про активність, цілеспрямованість і результативність діяльності людини, що забезпечує перетворення навколишнього світу в ії практичних потребах.

Дія, визначена в науковій літературі, як «фізична величина, що чисельно дорівнює добутку енергії на час ..., складова, або окремий акт діяльності, яка $є$ способом буття людини у світі, іï здатністю вносити в дійсність зміни» [10, с. 45], загалом може бути витлумачена як один із актів діяльності суб'єкта, спрямований на досягнення певного результату. Визначальною ознакою дії як явища дійсності $\epsilon$ свідома активність суб'єкта, який іiі реалізує, та наявність об'єкта, на який вона спрямована.

Як денотат, дія репрезентована в мові передусім у семантиці дієслова, якому властиві такі специфічні категорійно-семантичні ознаки, як контрольованість, волюнтивність, каузативність, акціональність, перехідність, локалізованість у часі й потенційна спостережуваність [6, с. 116]. Волюнтивність 
передбачає залежність дії, яку здійснює суб'єкт, від його волі.

Акціональність як дієвий, динамічний компонент семантики є основним критерієм розмежування дієслів: вони або називають дію предмета, або як дію представляють існування предметів, їхні відношення, стани, якості [4, с. 159]. «У центрі дієслівної системи - підклас дієслів зі значенням дії, або акціональних, найповніше відображає категорійне значення дієслова як частини мови» [4, с. 60]. Каузативний елемент у дієсловах дії відповідає власне онтологічній сутності дії, наявності в іï складі елементів мети i результату, бо його визначають «як можливість зробити так, щоб стан (або якість) об'єкта був змінений шляхом застосування засобів впливу матеріалу, предметів» [5, с. 67]. Значення часової локалізованості відображає одномірність, асиметричність і незворотність часу, ця ознака віддзеркалює в семантиці дієслова конкретне місцеперебування дії в односпрямованому і незворотному потоці часу [5, с. 117].

3-поміж визначених ознак дієслова, яке позначає дію в українській мові, окремої уваги потребує сема 'спостережуваність', що вказує на денотативні ознаки такої дії, які суб’єкт (у широкому розумінні з позицій антропоцентризму мови) здатний вичленувати, зафіксувати, сприйняти за допомогою органів чуття, іншими словами - побачити, почути, відчути на дотик, нюх, смак i под. Справді, дія як результат цілеспрямованої активності має своє «формальне» вираження, пор.: Вона ходила по полю збирати полуниці, розбила два горичатка $і$ одну мисочку (Марко Вовчок) - В неділю вона ходила в ліс, вибирала кращий матеріал, розмірковувала $i$ розпитувала про ціни в лісників (М. Коцюбинський). Очевидно, що дієслівний предикат розбити повною мірою реалізує сему 'спостережуваність' з огляду на наочний результат, чого не можна сказати про предикат розмріятися, що позначає ментальний процес і не передбачає наочного підтвердження. 3 огляду на таку особливість у мовознавстві інколи висловлюють думку про те, що потенційна спостережуваність може бути однією з підстав для розмежування дієслів дії і стану, оскільки стан - явище внутрішне, локалізоване в самому суб'єкті, а дія - елемент навколишньої дійсності, зовнішній вияв активності суб'єкта у його стосунку до об’єкта, пор.: «Потенційна спостережуваність $\epsilon$ визначальною рисою дієслівних предикатів дії, бо саме дія має різні фізичні показники та параметри, які можна фіксувати за допомогою органів сприймання і представляти в різноманітних вимірах» [6, с, 117].

Однак аналіз мовного матеріалу не дає змоги погодитися 3 наведеним твердженням. Беззаперечним $є$ те, що не всі дієслівні одиниці, які так чи так виражають семантику дії, повною мірою реалізують сему 'спостережуваність' у ролі диференційної. Так, у реченні 3 часом я обдумував сю справу чимраз иирие (І. Франко) дієслівний предикат обдумувати, попри вказівку на активність суб'єкта і результативність семантики, не засвідчує можливості сприйняти дію «сенсорно» (Г. Золотова), всупереч тому, що 
позначену ним денотативну ситуацію важко назвати станом чи якістю. Наведений приклад демонструє випадок нівеляції семи 'спостережуваність' у дієсловах дії, яка, однак, не дає підстав для переходу дієслівних лексем до інших семантичних класів, як-от 'стан', 'процес', 'якість', 'буття' тощо. Принагідно можна зауважити, що така нівеляція без їі проекції на загальну семантичну належність дієслова позбавляє сему 'спостережуваність' статусу диференційної й обов’язково властивої дієслову дії.

Нівеляція семи 'спостережуваність' у семантиці означає репрезентацію, позначення дієслівною лексемою такого типу дії, яка не може бути зафіксована в чуттєвому досвіді суб'єкта. До таких дій належать передусім інтелектуальні (ментальні, розумові, мисленнєві), емоційні, фізіологічні дії суб’єкта. Г. Золотова зараховує такі дієслова до розрядів, які представляють периферію акціонального підкласу, оскільки вони «виражають акціональність не в повному наборі, 3 варіаціями. Спостережуваність у них знижується в міру ускладнення номінованого процесу: спостережуваний окремий відрізок процесу не завжди достатньо мотивує його найменування певним дієсловом» [4, с. 61].

Найпоказовішими в аналізованому аспекті є дієслова інтелектуальних дій. Інтелектуальні, або розумові дії, - це дії суб’єкта, виконувані у свідомості без проекції й використання зовнішніх засобів, зокрема мовлення. Цим розумові дії відрізняються від інших видів суб'єктної діяльності (фізичних дій, руху й переміщення, мовлення тощо). Інтелектуальні дії позначені в українській мові дієсловами аналізувати, вирімувати, обдумувати, осмислювати, порівнювати, класифікувати та ін., наприклад: Я аналізував змивки з його реторт, вони були начисто змиті сірчаним квасом (М. Йогансен); На підтвердження витягала альбоми з пожовтілими фотографіями $і$ порівнювала з живою Іванкою, яку садовила навпроти себе (О. Чинилук). Групі наведених дієслів властиве термінологічне різноманіття: їх називають дієсловами розумової діяльності, інтелектуальних дій, ментальними дієсловами, дієсловами пропозитивного відношення, фактивними, епістемічними дієсловами тощо $[1 ; 2 ; 3 ; 7 ; 9]$. С. Омельченко стверджує, що такі термінологічні розбіжності засвідчують неоднозначне розуміння системних i функціональних характеристик цих дієслівних лексем [9, с. 11]. На нашу думку, під час розгляду дієслів на зразок обдумувати, осмислювати, обмірковувати слід застосовувати термін «інтелектуальна дія», оскільки він якнайточніше репрезентує уявлення дослідника про денотативне явище, позначене дієсловами, що стосуються активного суб’єкта, діяльність якого спрямована на об'єкт (у цьому разі - делібератив).

У сучасній лінгвістиці дедалі більше приділяють увагу вивченню ментальних процесів і структур, які специфічно представлені в мові. Дослідження в теорії ментальності свідчать, що в науці досі немає чіткого 
уявлення про цей феномен, розкриті лише окремі проблеми й розроблені шляхи їх вирішення (Апресян, 1995; Арутюнова, 1999; Булигіна, Шмельов, 1997; Вежбицька, 1996; Колесов, 1999; Кубрякова, 1997 та ін.).

Поза всяким сумнівом, ментальна діяльність суб'єкта відрізняється від фізичної, що знаходить своє відображення і в мові. Розумові дії можуть бути спрямовані на пізнання, вирішення логічних завдань, запам'ятовування, узагальнення практичного досвіду і навіть фіксування емоційних станів. Із теорії психології доцільно звернути увагу на традиційне розмежування загальних інтелектуальних дій (аналіз, синтез, аналіз через синтез, порівняння, абстрагування, узагальнення, аналогія, класифікація) та специфічних ментальних дій, властивих суб’єкту в певній ситуації і за певних умов. При цьому, попри відсутність спостережуваності і зовнішньої вираженості, інтелектуальна дія має низку ознак, які дають підстави розглядати цей феномент у межах семантичної категорії 'дія', а дієслівні лексеми, що їі позначають, зараховувати до розряду акціональних.

По-перше, суб’єкт, який виконує інтелектуальні дії, є активним. Категорійна ознака активного суб’єкта дії співвідносна 3 термінами «агентивний», «агент», «агент», «виконавець», «діяч», бо активність характеризує суб’єктну синтаксему як агента, діяча, виконавця певних дій, наділеного енергією, волею, усвідомленістю докладених до здійснення чого-небудь зусиль, наприклад: Він раз у раз бігав на руїни, щцось обмірковував, прикидав, вираховував. Потому бігав по людях, розпитував, пускав поголоски, $і$ коли вони знов доходили до його, значно змінені $i$ більи рімучі, він радів, хвалився Маланці і вірив (М. Коцюбинський).

По-друге, дія, названа інтелектуальною, розумовою, мисленнєвою може бути схарактеризована як контрольована. Контрольованість у значенні дієслів дії засвідчує згорнуту ситуацію, за якої дії суб’єкта свідомо спрямовані на зміну властивості чи стану об'єкта. Сема 'контрольованість' пов'язана з наявністю чи відсутністю в синтаксичній структурі агенса особи-діяча, що внаслідок свого волевиявлення контролює власні дії, які можна розцінювати як цілеспрямовані. Цілеспрямованість, у свою чергу, імплікує в собі розуміння того, що суб'єкт організовує й виконує дії свідомо, із власної волі, а також передбачає досягнення певного результату, наприклад: Славка почала прагнути ще і ще таких зустрічей. Вона вираховувала, коли не було Юрка в канцелярї (канцелярія була на ттопепсі. а їх помешкання в партері), йшла туди, спочатку під якимось банальним приводом, а згодом і без нього (О. Чинилук).

Семантичний компонент 'контрольованість' передбачає, що суб'єкт виступає ініціатором тієї чи тієї події, докладає зусиль для їі виконання, визначає об'єкт своєї дії, результат і інструмент. Це повною мірою стосується суб'єкта, який здійснює ту чи ту інтелектуальну дію, наприклад: Читач став біля вікна і замислився (М. Хвильовий). Контрольованість 
відрізняє дієслова інтелектуальної дії від дієслів фактивних і дієслів сприйняття, для яких показовою $є$ відсутність цього семантичного компонента.

По-третє, дієсловам інтелектуальної дії властива спрямованість на об'єкт, що зумовлено власне природою людського мислення: «Процес мислення завжди передбачає спрямованість думки суб'єкта на об'єкт, який може бути прямим чи опосередкованим, експліцитним чи імпліцитним, конкретним чи абстрактним, істотою чи неістотою тощо» [9, с. 12]. Інколи в семантичній структурі таких дієслів, як мислити, розмірковувати, думати, немає вказівки на прямий об'єкт, однак сама здатність суб'єкта мислити конкретно чи абстрактно передбачає наявність опосередкованого об'єкта думки, без якого процес мислення неможливий.

С. Омельченко називає модель «суб'єкт, що мислить - процес думки об'єкт думки», властиву семантиці ментальних дієслів і таку, що узагальнено передає сутність відображеної типової ситуації мислення, ідентифікатором, який слугує основою лінгвістичного опису ментальної дієслівної лексики [9, с. 12]. Спрямованість дії на об'єкт є визначальним показником для всіх дієслівних предикатів дії, співвідносних із активним суб'єктом.

Об'єкт при дієсловах інтелектуальної дії є деліберативним. Це означає, що він представляє тему, зміст думки, предмет ментальної спрямованості, на який дія спрямована умовно, опосередковано [8, с. 166]. Названа особливість об'єктної синтаксеми дає підстави дослідникам ототожнювати дієслова інтелектуальної дії з дієсловами мовлення, для реалізації семантики яких застосовна однакова модель із активним суб'єктом (агентом) і об’єктом-деліберативом. Сдиною відмінністю між цими предикатами є актуалізація семи 'спостережуваність' у дієсловах мовлення і іiі ж нівеляція в дієсловах інтелектуальної дії, пор.: Він говорив про гнів римського можновладия (О. Гончар) - Хлопець думав про вчорашню подію (І. Білик). Аналогічність базової моделі речень із цими двома типами дієслівних предикатів та ідентичність їхніх структурних схем, у свою чергу, є підставою до зарахування ментальних дієслів до семантичного класу дієслів дії.

Отже, наведені особливості ментальних дієслів й ознаки, які мають регулярне вираження в семантичній структурі цих одиниць, засвідчують їхню належність до класу дієслів дії. При цьому нівеляція семи 'спостережуваність' як однієї з показових для семантичної категорії 'дія' в українській мові має нерепрезентативний характер, оскільки не впливає на категорійний статус дієслів. Це, у свою чергу засвідчує, що аналізована сема не може бути представлена як диференційна i, очевидно, для семантики акціональних дієслів вона має супровідний, уточнювальний характер.

\section{Література}

1. Арутюнова Н. Д. Язык и мир человека / Нина Давидовна Арутюнова. - М. : Языки русской культуры, 1999. - 896 с. 
2. Булыгина Т. В. К построению типологии предикатов в русском языке / Т. В. Булыгина // Семантические типы предикатов : [монография] / [отв. ред. О. Н. Селиверстова]. - М. : Наука, 1982. - С. 7-85.

3. Булыгина Т. В. Языковая концептуализация мира (на материале русской грамматики) / Т. В. Булыгина, А. Д. Шмелев. - М. : Школа «Языки русской культуры», 1997. - 574 с.

4. Золотова Г. А. Коммуникативные аспекты русского синтаксиса / Г. А. Золотова. М. : КомКнига, 2007. - 366 с.

5. Лазуткина Е. М. Синтагматический класс глаголов: языковая данность, концептуальный феномен, коммуникативный стереотип / Е. М. Лазуткина // Научн. докл. высш. шк. : Филологические науки. - 1995. - №5-6. - С. 65-78.

6. Леута О. І. Структура і семантика дієслівних речень в українській літературній мові : [монографія] / О. І. Леута. - К. : Такі справи, 2008. - 208 с.

7. Логический анализ языка : Знание и мнение : [сб. науч. тр.]. / отв. ред. Н. Д. Арутюнова. - М. : Наука, 1988. - 126 с.

8. Мустайоки А. Теория функционального синтаксиса : От семантических структур к языковым средствам : [монография] / Арто Мустайоки. - М. : Языки славянской культуры, 2006. - 512 с.

9. Омельченко С. Р. Функционально-семантическая характеристика русских ментальных глаголов / С. Р. Омельченко // Гуманитарные науки. - Вып. 7 : «Филология». - 2004. - № 31. - С. 9-20.

10. Філософський енциклопедичний словник / В. І. Шинкарук (голова редколегії). К. : Абрис, 2002. - 742 с. 